\title{
Therapeutic angiogenesis in patients with severe limb ischemia by transplantation of a combination stem cell product
}

\author{
Gabriel P. Lasala, MD, FACC, Jose A. Silva, MD, FACC, and Jose J. Minguell, PhD
}

\begin{abstract}
Objective: Angiogenesis involves the interplay of endothelial progenitor cells, pericytes, growth factors, and cellular matrix components. The use of mesenchymal stem cells, which are closely related to pericytes and produce diverse angiogenic growth factors and matrix molecules, seems to be a promising therapeutic modality. We postulate that the use of a combination cell product (mesenchymal stem cells in conjunction with a source of endothelial progenitor cells) is safe and efficient and may optimize the clinical results obtained with the use of endothelial progenitor cells alone. This study assessed whether the intramuscular infusion of a combination cell product represents a viable, effective, and lasting therapeutic modality to improve perfusion in severely ischemic limbs.
\end{abstract}

Methods: Patients with limb ischemia $(\mathrm{n}=26)$ received an intramuscular (gastrocnemius) infusion of the combination cell product in the most ischemic leg and a placebo product in the (less ischemic) contralateral leg. Clinical follow-up (months $0.5,1,2$, and 4 postinfusion) included evaluation of pain-free walking time, ankle-brachial index, perfusion scintigraphy, and quality of life survey.

Results: No adverse events occurred after infusion. Efficacy assessment indicated that after cell infusion there was a significant improvement in walking time and ankle-brachial index. In addition, technetium-99mtetrofosmin scintigraphy demonstrated a significant increase of perfusion in the treated limbs compared with the respective control legs.

Conclusions: This phase II clinical trial shows that the use of a combination cell therapy is safe and effective in increasing blood flow in the ischemic legs of patients with limb ischemia. (J Thorac Cardiovasc Surg 2012;144:377-82)

During the last few years, therapeutic angiogenesis using different populations of stem cells has emerged as a viable therapeutic modality of last resource for patients with critical limb ischemia not eligible for other revascularization procedures. ${ }^{1,2}$ The rationale for the use of this therapy is based on the notion that in addition to adult neovascularization from preexisting vasculature, postnatal vasculogenesis mediated by bone marrow (BM)-resident or circulating endothelial progenitor cells (EPCs) also occurs in adults. ${ }^{3,4}$ Several reports have demonstrated that the infusion of a source of EPCs ${ }^{5}$ into critically ischemic limbs facilitates blood vessel repair and improves clinical outcomes. ${ }^{6-10}$

New blood vessel formation entails several steps, including proliferation and migration of EPCs, lumen formation, basement membrane assembling, recruitment of pericytes/

\footnotetext{
From TCA Cellular Therapy, LLC, Covington, La.

Disclosures: TCA Cellular Therapy is a private research company owned by health care professionals. The authors involved in the study own stocks in the company. The funding to perform the research has come from individual physician investors who strongly believe in stem cell therapies.

Clinical Trial Registry Number: phase II clinical study (BB-IND 13139); ClinicalTrials.gov Identifier: NCT00721006.

Received for publication July 26, 2011; accepted for publication Aug 4, 2011; available ahead of print Nov 14, 2011

Address for reprints: Jose J. Minguell, PhD, TCA Cellular Therapy, LLC, 101 E Fairway Dr, Suite 514, Covington, LA 70433 (E-mail: drminguell@tcaway.com). $0022-5223 / \$ 36.00$

Copyright (c) 2012 by The American Association for Thoracic Surgery doi:10.1016/j.jtcvs.2011.08.053
}

vascular smooth muscle cells, vascular maturation, and ultimately blood flow. This sequence is orchestrated by several growth factors that play pivotal roles. ${ }^{4,11,12}$ The absence of any of these steps produces blood vessels that are immature, permeable, and leaky. ${ }^{13}$

Because mesenchymal stem cells (MSCs) are involved in smooth muscle cell and pericyte formation, as well as in the manufacturing of several growth factors and extracellular matrix molecules implicated in blood vessel formation, ${ }^{14-18}$ we believe the use of a combination of MSC and EPCs may be more effective than the use of a single cell type (EPCs) for the development of a mature and stable blood vessel.

In a previous phase I study, ${ }^{19}$ we assessed the feasibility and safety of a combination stem cell product including EPCs and MSC to treat patients with severe limb ischemia. After $10 \pm 2$ months of follow-up, efficacy assessment demonstrated improvements in walking time, ankle-brachial index (ABI), and quality of life (QoL). Angiographic evaluation and technetium-99m-tetrofosmin (99mTc-TF) perfusion scintigraphy scores confirmed increased perfusion in the affected limbs. The present phase II study was performed to further evaluate our findings from phase I.

\section{MATERIALS AND METHODS \\ Study Design}

This phase II clinical trial was a single-center, prospective, nonrandomized, open-label, placebo-controlled, safety/efficacy study of infusion of 


$$
\begin{aligned}
& \text { Abbreviations and Acronyms } \\
& \begin{array}{ll}
\text { ABI } & =\text { ankle-brachial index } \\
\mathrm{B} & =\text { brain } \\
\mathrm{BM} & =\text { bone marrow } \\
\mathrm{EPC} & =\text { endothelial progenitor cell } \\
\mathrm{M} & =\text { muscle } \\
\mathrm{MNC} & =\text { mononuclear cell } \\
\mathrm{MSC} & =\text { mesenchymal stem cell } \\
\text { 99mTc-TF } & =\text { technetium- } 99 \mathrm{~m}-\text { tetrofosmin } \\
\text { QoL } & =\text { quality of life }
\end{array}
\end{aligned}
$$

a combination stem cell product to the legs of patients with severe limb ischemia. This study was approved by the Western Institutional Review Board (Olympia, Wash), and all subjects signed the informed consent form.

The end point of the study was to determine whether the infusion of the cell product into the gastrocnemius muscle of ischemic limbs improves perfusion, as assessed by $99 \mathrm{mTc}-\mathrm{TF}$ perfusion scintigraphy, ABI, pain-free walking time, and QoL.

\section{Patient Population}

Twenty-six patients (Table 1) were enrolled from July 2008 to March 2010. The main inclusion criterion was the presence of severe limb ischemia, Rutherford class 4 to 6 in patients considered not candidates for percutaneous or surgical revascularization. The main exclusion criteria were previous angiogenic therapy, severe medical illness that could affect patients' survival after enrollment, and a history of myocardial infarction within the previous 3 months of screening.

\section{Clinical Assessment}

The more symptomatic (Rutherford class 4-6) leg was chosen to receive the infusion of cell product. These legs were subsequently randomly assigned to receive a low or high dose of the cell product, consisting of $900 \times 10^{6} \mathrm{BM}$ mononuclear cells (MNCs) and $9 \times 10^{6} \mathrm{BM}-\mathrm{MSC}$ and $1800 \times 10^{6} \mathrm{BM}-\mathrm{MNC}$ and $18 \times 10^{6} \mathrm{BM}-\mathrm{MSC}$, respectively. The less symptomatic leg was used as control and received a placebo infusion.

The clinical condition of each leg was monitored by assessing the severity of ischemic pain, ABI, perfusion scintigraphy, and walking time. The health-related QoL of patients was assessed by a QoL survey (Vascular Quality of Life Questionnaire). In patients with ischemic ulcers, regular measurements of the ulcer size were obtained during every office follow-up.

\section{Cell Preparation}

All patients underwent a primary and secondary BM aspiration for preparation of BM-MSC and BM-MNC (as a source of EPCs), respectively. Cell processing was performed as previously published, ${ }^{19-21}$ followed by immunophenotypical characterization of MSC and EPCs by flow cytometry analysis (LSRII Analytic Flow Cytometer; Tulane National Primate Research Center, Covington, La).

\begin{tabular}{|c|c|c|c|c|}
\hline ID & $\begin{array}{l}\text { Patient characteristics } \\
\text { (sex, age, comorbidities) }\end{array}$ & $\begin{array}{l}\text { Rutherford } \\
\text { class }\end{array}$ & $\begin{array}{c}\text { Treated } \\
\text { leg }\end{array}$ & $\begin{array}{l}\text { Cell } \\
\text { dose }\end{array}$ \\
\hline 1 & M, 65 y, CAD, DM, HC, HTN, NHU & 6 & $\mathrm{R}$ & Low \\
\hline 2 & $\mathrm{M}, 53 \mathrm{y}, \mathrm{CAD}, \mathrm{HC}$ & 4 & $\mathrm{R}$ & Low \\
\hline 3 & M, 57 y, HC, NHU & 6 & $\mathrm{~L}$ & High \\
\hline 4 & M, 59 y, HC, HTN, NHU & 4 & $\mathrm{~L}$ & High \\
\hline 5 & M, 67 y, CAD, DM, HTN, HC & 4 & $\mathrm{~L}$ & High \\
\hline 6 & M, 61 y, CAD, HTN & 4 & $\mathrm{R}$ & High \\
\hline 7 & M, 73 y, CAD, DM, NHU, HTN & 6 & $\mathrm{~L}$ & High \\
\hline 8 & $\mathrm{~F}, 74 \mathrm{y}, \mathrm{CAD}, \mathrm{HTN}, \mathrm{HC}$ & 4 & $\mathrm{~L}$ & Low \\
\hline 9 & $\mathrm{~F}, 69 \mathrm{y}, \mathrm{CAD}, \mathrm{HTN}$ & 4 & $\mathrm{~L}$ & Low \\
\hline 10 & M, 51 y, CAD, HTN, HC & 4 & $\mathrm{R}$ & Low \\
\hline 11 & $\mathrm{M}, 55 \mathrm{y}, \mathrm{CAD}, \mathrm{DM}, \mathrm{HTN}$ & 4 & $\mathrm{~L}$ & Low \\
\hline 12 & $\mathrm{M}, 70 \mathrm{y}, \mathrm{CAD}, \mathrm{DM}$ & 4 & $\mathrm{~L}$ & Low \\
\hline 13 & $\mathrm{M}, 63 \mathrm{y}, \mathrm{DM}, \mathrm{HC}$ & 4 & $\mathrm{~L}$ & High \\
\hline 14 & $\mathrm{~F}, 72 \mathrm{y}, \mathrm{HC}$ & 4 & $\mathrm{~L}$ & High \\
\hline 15 & F, 57 y, CAD, DM, HC, HTN & 4 & $\mathrm{~L}$ & High \\
\hline 16 & M, 76 y, CAD, DM, HC, HTN & 4 & $\mathrm{R}$ & High \\
\hline 17 & $\mathrm{M}, 48$ y, CAD, NHU & 6 & $\mathrm{R}$ & High \\
\hline 18 & $\mathrm{M}, 73$ y, CAD, HC, HTN & 4 & $\mathrm{~L}$ & High \\
\hline 19 & M, 56 y, CAD, DM, HC, HTN, NHU & 4 & $\mathrm{R}$ & High \\
\hline 20 & $\mathrm{M}, 67 \mathrm{y}, \mathrm{CAD}, \mathrm{DM}, \mathrm{HC}, \mathrm{HTN}$ & 4 & $\mathrm{R}$ & High \\
\hline 21 & $\mathrm{M}, 48$ y, CAD, HC, NHU & 5 & $\mathrm{R}$ & High \\
\hline 22 & $\mathrm{M}, 87 \mathrm{y}, \mathrm{CAD}, \mathrm{HC}, \mathrm{HTN}$ & 4 & $\mathrm{R}$ & Low \\
\hline 23 & $\mathrm{M}, 74 \mathrm{y}, \mathrm{CAD}, \mathrm{DM}, \mathrm{HC}$ & 4 & $\mathrm{R}$ & Low \\
\hline 24 & F, 59 y, CAD, DM, HC, HTN & 4 & $\mathrm{R}$ & Low \\
\hline 25 & $\mathrm{M}, 66$ y, CAD, HC, NHU & 6 & $\mathrm{~L}$ & Low \\
\hline 26 & F, 53 y, CAD & 4 & $\mathrm{~L}$ & Low \\
\hline
\end{tabular}

\section{Preparation and Infusion of the Cell and Placebo Products}

The cell product for infusion was prepared by taking proper aliquots of BM-MSC and BM-MNC into a final volume of $20.0 \mathrm{~mL}$ of infusion medium (Dulbecco's phosphate-buffered saline containing 5\% human serum albumin). The cell suspension was filtered through a cell strainer (BD Falcon, nylon, $100 \mu \mathrm{m}$; Bedford, Mass), and aliquots were taken for cell count, viability, and microbiological control. As soon as the cell product was
TABLE 1. Clinical characteristics of the study population

$M$, Male; $C A D$, coronary artery disease; $D M$, diabetes mellitus; $H C$, hypercholesterolemia; $H T N$, hypertension; $N H U$, nonhealing ulcer; $L$, left; $R$, right; $F$, female.

approved for infusion (lot-release criteria), portions $(0.5 \mathrm{~mL})$ of the cell suspension were transferred to forty $1-\mathrm{mL}$ syringes. For placebo product infusion, forty $1-\mathrm{mL}$ syringes were prepared, each containing $0.5 \mathrm{~mL}$ of infusion media.

Release criteria for cell infusion was based on (1) no growth results for USP Sterility (Fluid Thioglycollate Media and Soybean Casein Digest Medium), (2) negative results for mycoplasma testing (polymerase chain reaction), (3) negative result for a Gram stain test, and (4) a cell viability (Trypan blue exclusion) $95 \%$ or greater. In addition, endotoxin content in the cell product for infusion should be patient body weight of $5 \mathrm{EU} / \mathrm{kg}$ or less.

After the cell product was approved by the lot-release criteria, cells were infused in 4 areas of the gastrocnemius muscle of the treated leg. For this, the muscle was divided into 4 quadrants and the cell product (in 40 syringes) was evenly infused. Under similar conditions, the placebo product was infused into the control leg.

\section{Clinical Assessment After Cell Infusion}

Follow-up was obtained at 2 weeks and 1,2, and 4 months after infusion. During each visit, every patient underwent vital sign monitoring, chemistry panel, complete blood count, resting ABI, pain-free walking time and distance on a treadmill (at $2.4 \mathrm{~km} / \mathrm{h}$, with no incline), and rest pain measurement using a visual analog scale score. ${ }^{22}$

To assess leg perfusion, $99 \mathrm{mTc}-\mathrm{TF}$ perfusion scintigraphy was performed for each leg at baseline and months 1 and 4 after infusion. For this, average counts per pixel in posterior projections of muscle regions of equal size (M) and in brain (intracranial uptake, B) were drawn and the muscle-to-brain uptake (M/B) ratio was calculated. ${ }^{7}$ The changes in 

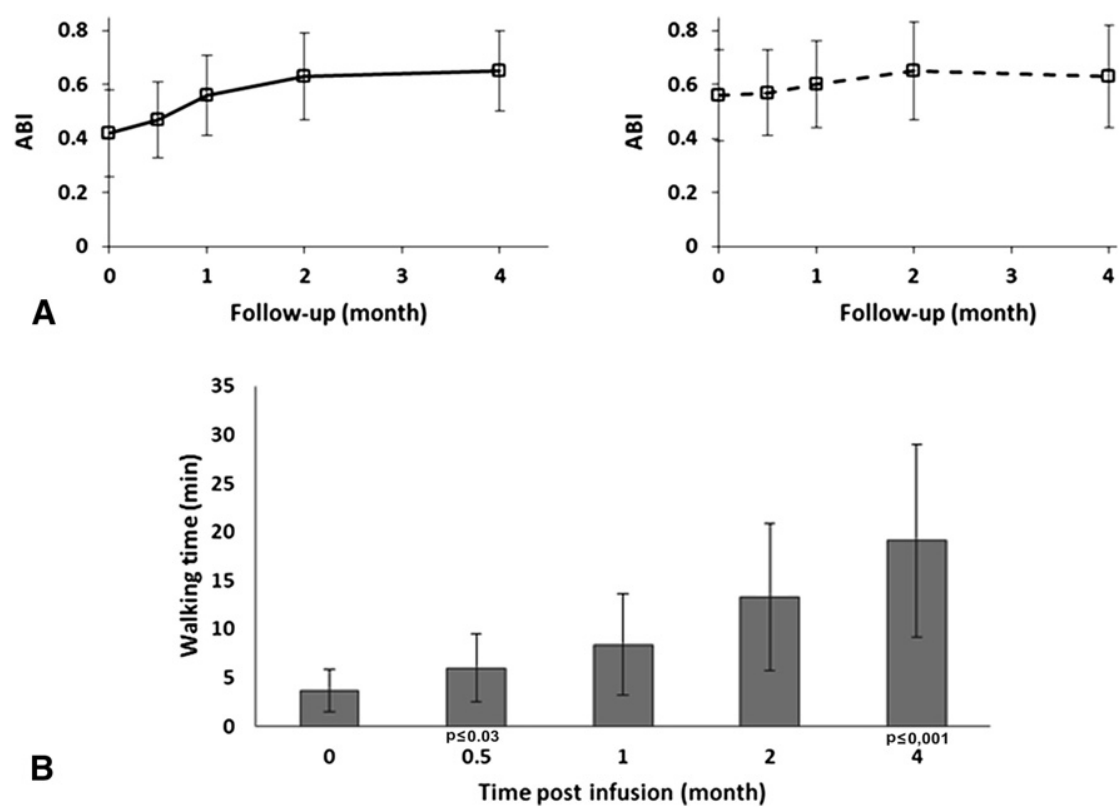

FIGURE 1. A, Changes in ABI for control and treated legs during follow-up. Left: $\mathrm{ABI}$ (mean \pm standard deviation) for control legs; $P$ values at months 1 and 4 were $\geq .05$ in both cases. Right: ABI (mean \pm standard deviation) for treated legs; $P$ values at months 1 and 4 were $\leq .05$ and $\leq .01$, respectively. B, Pain-free walking time during follow-up. As noted, there is a gradual increment from the time of infusion to the last follow-up (month 4 ); $P$ values at months 5 and 4 were $\leq .03$ and $\leq .001$, respectively. $A B I$, Ankle-brachial index.

limb perfusion, as assessed by analysis of the M/B ratio, were confirmed by analysis of the perfusion scintigraphy planar images taken on the legs of all patients at baseline and months 1 and 4. Eleven patients returned for follow-up (mean of $17 \pm 6$ months) after the protocol had been concluded. In these patients, $\mathrm{ABI}$ and QoL scores were recorded.

\section{Data and Statistical Analysis}

Statistical analysis was performed with NCSS statistical software (Kaysville, Utah). All data are expressed as mean \pm standard deviation.

\section{RESULTS \\ Processing Time and Characterization of the Cell Product}

The average time elapsed from BM aspiration to completion of MSC expansion and infusion procedures was $24.6 \pm$ 5.9 days. During this period, MSCs undergo the equivalent of $2 \pm 1$ passages after the primary culture (colony-forming units fibroblasts). Although the time required to obtain the final number of MSC targeted for infusion (low or high dose) proved not to be significantly dependent on cell number, it was directly correlated with patient's age, presence and nature of comorbidities, and type of medication taken (data not shown).

The combination cell product consisted of a population of ex vivo expanded BM-MSCs characterized by a high expression of the mesenchymal antigens CD73, CD90, and CD105 and a negative/dim expression of the myeloid surface antigens CD45 and CD34, ${ }^{23}$ as well as a subset of EPC-like cells (among the $\mathrm{CD} 45^{+}$population of BMMNC), coexpressing antigens CD144, CD133, and CD $34 .{ }^{24}$

\section{Procedural Safety}

There were no procedural complications related to BM aspirations. The intramuscular cell infusion procedure was well tolerated with no or only mild discomfort. The adopted release criteria for cell infusion proved to be appropriate and dependable, because infusion-related complications in the first 24 hours did not develop in any patient. No adverse events of the index or contralateral control limb were identified during the first 48 hours after infusion or the follow-up period.

\section{Ankle-Brachial Index}

In 5 of 26 patients, $\mathrm{ABI}$ assessment was not possible because of partial or total arterial wall calcification of the treated leg. In all 21 patients with available ABI, the index of the treated legs significantly increased compared with baseline, as early as 1 month after cell infusion $(P \leq .05)$. This effect persisted $(P \leq .001)$ during the entire followup period. In contrast, there were no significant changes of the ABIs in the contralateral (control) leg after placebo

TABLE 2. Ankle-brachial index assessment at baseline, last, and postlast study visits

\begin{tabular}{lcc}
\hline \multicolumn{3}{c}{ ABI (mean \pm SD) } \\
\hline Baseline & $\begin{array}{c}\text { Last study visit } \\
(\text { month 4) }\end{array}$ & $\begin{array}{c}\text { Postlast study visit* } \\
(\text { month 16.8 } \pm \text { 5.9) }\end{array}$ \\
\hline $0.45 \pm 0.12$ & $0.66 \pm 0.16(P=.023)$ & $0.62 \pm 0.14(P=.062)$ \\
\hline $\begin{array}{l}S D, \text { Standard deviation. *Data for the 14 patients who returned for follow-up after the } \\
\text { last study visit of the protocol. The average time for postlast visits was } 16.8 \pm 5.9 \\
\text { months after infusion of the combination cell product. }\end{array}$
\end{tabular}


TABLE 3. 99mTc-TF perfusion scintigraphy analysis during follow-up

\begin{tabular}{|c|c|c|}
\hline \multicolumn{3}{|c|}{ M/B ratio* $($ average $\pm S D, n=23 \dagger)$} \\
\hline Baseline & Month 1 & Month 4 \\
\hline 1 & $1.20 \pm 1.54(P \geq .05)$ & $1.54 \pm 0.54(P=.03)$ \\
\hline $\begin{array}{l}S D, \text { Standa } \\
\text { used to calc } \\
\text { values at ba } \\
1 \text { and } 4 \text {. }\end{array}$ & $\begin{array}{l}\text { n. *For each patient, the } \\
\text { elative } M / B \text { ratio at month } \\
\text { e unreliable and thus not us }\end{array}$ & $\begin{array}{l}\text { t baseline was set to } 1 \text { and } \\
\dagger \text { In } 3 \text { of } 26 \text { patients, M/B } \\
\text { ulate } \mathrm{M} / \mathrm{B} \text { ratios at months }\end{array}$ \\
\hline
\end{tabular}

infusion (Figure 1, A). The favorable effect of cell infusion in ABI was not correlated with cell dose because both low and high cell dose products elicited an increment in ABI of similar magnitude.

Fourteen patients returned for follow-up after the protocol had been concluded (after last visit study, $16.8 \pm 5.9$ months). The ABI in these individuals (Table 2) was 0.62 \pm 0.14 , which is not different from the ABI recorded at the last study visit (month 4 of follow-up).

\section{Walking Time}

Pain-free walking time increased in all patients after cell infusion. As seen in Figure 1, $B$, improvement in pain-free walking time was observed in all patients, as early as 2 weeks after cell infusion $(P \leq .03)$, and continued increasing until the end of follow-up $(P \leq .001)$. In each patient, the increase in pain-free walking time correlated with a change in pain severity and relief, as reported in the visual analog scale.

\section{Quality of Life}

QoL scores increased from $2.22 \pm 0.64$ units to $3.24 \pm$ 1.08 units $(P \leq .05)$ from baseline to month 4 after infusion, respectively. The improvement in QoL was primarily due to pain relief and improvement of physical functioning. All patients reported satisfaction with the results of cell treatment and recognized that the relief of pain in 1 leg (treated) allows them to enhance their activity level, including walking and a significant reduction in the use of analgesics. In 16 patients who returned for a postlast study visit, the QoL score revealed stabilization or improvement of symptoms compared with the last 4-month follow-up.

\section{9mTc-TF Perfusion Scintigraphy}

The average (M/B) ratio calculated for legs infused with the cell product showed a modest but not significant increase from baseline to 1 month after infusion. However, a significant increase in $\mathrm{M} / \mathrm{B}$ ratio was observed 4 months after cell infusion $(P \leq .05)$ (Table 3$)$. In the contralateral control legs, the $\mathrm{M} / \mathrm{B}$ ratios at baseline and at month 4 after infusion were similar (data not shown).

In Figure 2, planar images of the posterior projection (region from knee to ankle) for the treated legs of 2 patients are shown. The increase in radioactive tracer (from baseline to month 4) sustains the assumption that the cell product enhances limb perfusion, as suggested by data in Table 3 .

\section{Chronic Ischemic Ulcers}

We observed significant improvement or complete healing of chronic ischemic ulcers in 6 patients with this condition, which had not improved or healed before cell infusion using conventional wound therapy (Figure 3).

\section{DISCUSSION}

In the present phase II clinical investigation, we confirm our previous findings that the use of a BM-derived combination stem cell product is safe. ${ }^{19}$ None of the 26 patients participating in this clinical trial developed procedural complications after BM aspiration or after cell infusion into the gastrocnemius muscle. Furthermore, at 4 months of follow-up, none of the patients reported side effects related to cell infusions.

In addition, our results strongly suggest that the use of a stem/progenitor cell product increases a limb's blood flow and improves claudication symptoms of limb ischemia. This was demonstrated by a significant increase in $\mathrm{ABI}$, perfusion scintigraphy, and pain-free walking distance

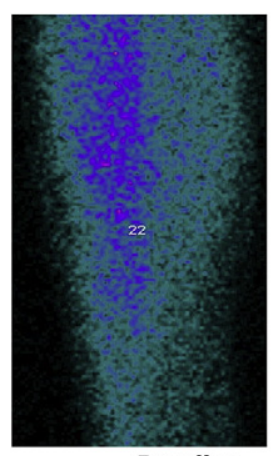

Baseline

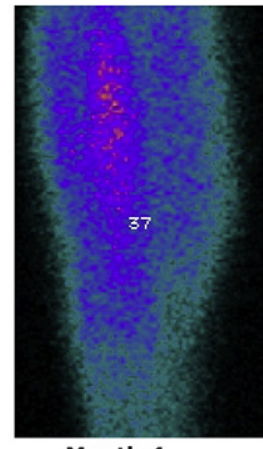

Month 4

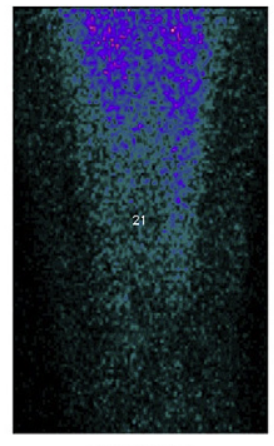

Baseline

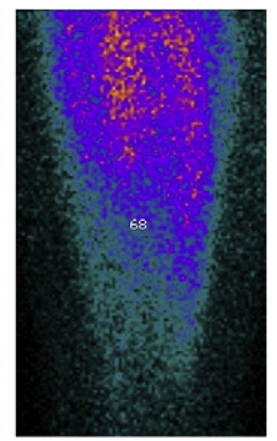

Month 4

FIGURE 2. Visual analysis of calf perfusion using 99mTc-TF scintigraphy. Posteroanterior views at baseline and month 4 after infusion for patients 5 (left) and 23 (right). 


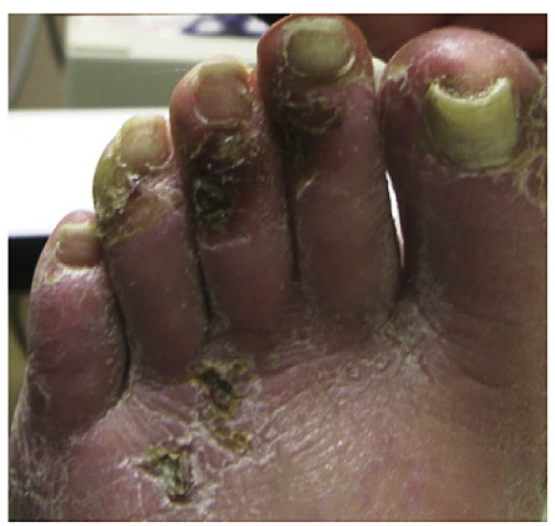

Baseline

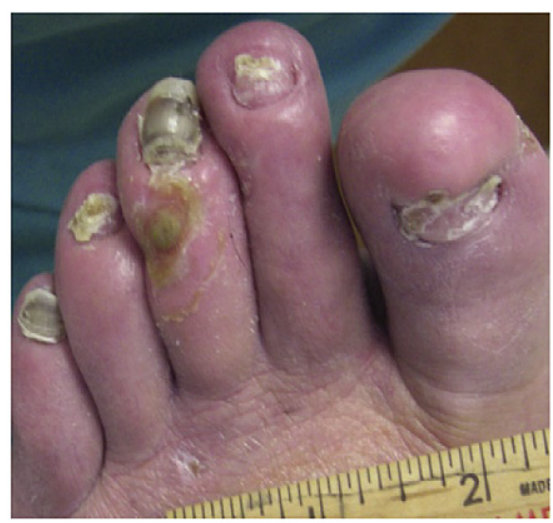

Month 4

FIGURE 3. Healing of ischemic ulcers. Compared with baseline, a significant healing and improvement of an ischemic ulcer in the third toe and complete healing in the second toe (patient 1) are seen 4 at months after cell infusion. Representative data.

after cell infusion. Furthermore, we observed a dramatic improvement or complete healing in all 6 patients with chronic ischemic ulcers. All patients reported symptoms of improvement in the questionnaire of QoL and a decrease in analgesics consumption. In contrast, in the contralateral placebo control leg, there were no changes in ABI or perfusion scintigraphy.

It is important to mention that all patients recognized and were aware of major clinical improvements in the treated (more ischemic) leg, despite no significant clinical changes in the control (less ischemic) leg.

The cell doses used in this study were $30 \%$ and $60 \%$ lower than that used in our phase I study ${ }^{19}$; however, in all cases, the ratio of stem/progenitor (MSC to EPCs) cells was 1 . Accordingly, it seems that the beneficial effect in clinical outcomes is more related to the presence of a repertoire of stem/progenitor repair cells rather than the absolute number of infused cells. Previous studies have yielded beneficial clinical outcomes by the infusion of different doses of a single cell product (EPCs from diverse sources) to patients with limb ischemia after a relatively short (2-month) follow-up. ${ }^{2,6,7}$ This makes it difficult to make meaningful comparisons with the current study.

We assume that the addition of MSCs to the cell product may play an important role in modulating and enhancing the reported effect of MNCs in promoting neovascularization in ischemic tissue. ${ }^{2}$ In addition to EPCs, formation of new mature blood vessel requires the coordinated participation of mural cells (vascular smooth cells and pericytes) and the availability of local/distant growth factors, chemokines, and extracellular matrix molecules. ${ }^{12-16}$ Thus, the infusion of a combination cell product containing a source of EPCs and MSCs may be critical to enhance angiogenesis and to promote ischemic tissue repair. Whether the clinical improvement is due to angiogenesis or an increase in collateral remodeling ${ }^{25}$ by MSC remains speculative at this stage.

\section{CONCLUSIONS}

The present results clearly suggest that this therapy is effective for the treatment of severe limb ischemia. Further investigation will be needed to determine the mechanism of action involved in the clinical effect elicited by the combination stem cell therapy. The present study also shows that this therapy is not only effective but also has persistent benefits beyond the 4-month follow-up. In the group of patients who were contacted after the end of the study $(16.8 \pm 5.9$ months after cell infusion), the ABI and QoL scores were similar to those recorded at the last follow-up visit (4 months). Thus, the combination cell therapy used seems to be effective in triggering a long-term and sustained clinical effect. To our knowledge, this is the first study in the United States that proves the feasibility, safety, and efficacy of using a stem cell combination therapy in patients with limb ischemia. In addition, evidence indicates that the beneficial effect persists with time.

The authors thank all the study investigators, coordinators, and patients who participated in this phase II clinical trial.

\section{References}

1. Kolvenbach R, Kreissig C, Ludwig E, Cagiannos C. Stem cell use in critical limb ischemia. J Cardiovasc Surg. 2007;48:39-44.

2. Sprengers RW, Lips DJ, Moll FL, Verhaar MC. Progenitor cell therapy in patients with critical limb ischemia without surgical options. Ann Surg. 2008;247:411-20.

3. Zammaretti P, Zisch AH. Adult 'endothelial progenitor cells.' Renewing vasculature. Int J Biochem Cell Biol. 2005;37:493-503.

4. Kässmeyer S, Plendl J, Custodis P, Bahramsoltani M. New insights in vascular development: vasculogenesis and endothelial progenitor cells. Anat Histol Embryol. 2009;38:1-11.

5. Leone AM, Valgimigli M, Giannico MB, Zaccone V, Perfetti M, D'Amario D, et al. From bone marrow to the arterial wall: the ongoing tale of endothelial progenitor cells. Eur Heart. 2009;30:890-9.

6. Tateishi-Yuyama E, Matsubara H, Murohara T, Ikeda U, Shintani S, Masaki H, et al. Therapeutic angiogenesis for patients with limb ischaemia by autologous transplantation of bone-marrow cells: a pilot study and a randomised controlled trial. Lancet. 2002;360:427-35.

7. Miyamoto M, Yasutake M, Takano H, Takagi H, Takagi G, Mizuno H, et al. Therapeutic angiogenesis by autologous bone marrow cell implantation for refractory chronic peripheral arterial disease using assessment of neovascularization by 
99mTc-tetrofosmin (TF) perfusion scintigraphy. Cell Transplant. 2004;13: 429-37.

8. Bartsch T, Brehm M, Zeus T, Kögler G, Wernet P, Strauer BE. Transplantation of autologous mononuclear bone marrow stem cells in patients with peripheral arterial disease (the TAM-PAD study). Clin Res Cardiol. 2007;96:891-9.

9. Capoccia BJ, Robson DL, Levac KD, Maxwell DJ, Hohm SA, Neelamkavil MJ, et al. Revascularization of ischemic limbs after transplantation of human bone marrow cells with high aldehyde dehydrogenase activity. Blood. 2009;113: 5340-51.

10. Burt RK, Testori A, Oyama Y, Rodriguez HE, Yaung K, Villa M, et al. Autologous peripheral blood CD133+ cell implantation for limb salvage in patients with critical limb ischemia. Bone Marrow Transplant. 2010;45:111-6.

11. Nowak G, Sumitran-Holgersson S. Expression of vascular endothelial growth factor receptor- 2 or Tie- 2 on peripheral blood cells defines functionally competent cell populations capable of reendothelialization. Circulation. 2004;110: 3699-707.

12. Jakobsson L, Franco CA, Bentley K, Collins RT, Ponsioen B, Aspalter IM, et al. Endothelial cells dynamically compete for the tip cell position during angiogenic sprouting. Nat Cell Biol. 2010;12:943-53.

13. Thurston G, Rudge JS, Ioffe E, Zhou H, Ross L, Croll SD, et al. Angiopoietin-1 protects the adult vasculature against plasma leakage. Nat Med. 2000;6:460-3.

14. Duffy GP, Ahsan T, O'Brien T, Barry F, Nerem RM. Bone marrow-derived mesenchymal stem cells promote angiogenic processes in a time- and dosedependent manner in vitro. Tissue Eng Part A. 2009;15:2459-70.

15. Armulik A, Abramsson A, Betsholtz C. Endothelial/pericyte interactions. Circ Res. 2005;97:512-23.

16. Covas DT, Panepucci RA, Fontes AM, Silva WA Jr, Orellana MD, Freitas MC, et al. Multipotent mesenchymal stromal cells obtained from diverse human tissues share functional properties and gene-expression profile with CD146+perivascular cells and fibroblasts. Exp Hematol. 2008;36:642-54.

17. Grunewald M, Avraham I, Dor Y, Bachar-Lustig E, Itin A, Jung S, et al. VEGFinduced adult neovascularization: recruitment, retention, and role of accessory cells. Cell. 2006;124:175-89.

18. Stratman AN, Malotte KM, Mahan RD, Davis MJ, Davis GE. Pericyte recruitment during vasculogenic tube assembly stimulates endothelial basement membrane matrix formation. Blood. 2009;114:5091-101.

19. Lasala GP, Silva JA, Gardner PA, Minguell JJ. Combination stem cell therapy for the treatment of severe limb ischemia: safety and efficacy analysis. Angiology. 2010;61:551-6.

20. Conget P, Minguell JJ. Phenotypical and functional properties of human bone marrow mesenchymal progenitor cells. J Cell Physiol. 1999;181: $67-73$.

21. Minguell JJ, Fierro FA, Epunan MJ, Erices AA, Sierralta WD. Nonstimulated human uncommitted mesenchymal stem cells express cell markers of mesenchymal and neural lineages. Stem Cells Dev. 2005;14:408-14.

22. Myles PS, Troedel S, Boquest M, Reeves M. The pain visual analog scale: is it linear or nonlinear? Anesth Analg. 1999;89:1517-20.

23. Horwitz EM, Le Blanc K, Dominici M, Mueller I, Slaper-Cortenbach I, Marini FC, et al. Clarification of the nomenclature for MSC: The International Society for Cellular Therapy position statement. Cytotherapy. 2005; 7:393-5.

24. Prater DN, Case J, Ingram DA, Yoder MC. Working hypothesis to redefine endothelial progenitor cells. Leukemia. 2007;21:1141-9.

25. Kinnaird T, Stabile E, Burnett MS, Shou M, Lee CW, Barr S, et al. Local delivery of marrow-derived stromal cells augments collateral perfusion through paracrine mechanisms. Circulation. 2004;109:1543-9. 